\title{
Internal Displacement and the Developmental Debate
}

\author{
Dr Pallavi Hazarika
}

\begin{abstract}
This paper examines the politics associated with the construction of mega hydro electric projects in the northeastern region of India with the light of the ongoing protest movement against the Lower Subansiri Project in Assam. The issues of development induced displaced population by the project and their rehabilitation and resettlement will be analysed on the basis of the core issues raised by protesting organizations.
\end{abstract}

Keywords: Development, Displacement, Resettlement, Rehabilitation

\section{Introduction}

The concept of internal displacement is gaining currency in the contemporary world as a result of displacement of persons or groups of persons from their own habitats due to various factors, natural or man-made. It basically signifies a phenomenon in which people move around for settlement or settle in camps or adjust in temporary settlements with their own people or within their own locality, district, state or country without crossing the international border [1]. According to the Guiding Principles on Internally Displaced Persons, prepared by Francis Deng, the Representative of the United Nations secretary General on Internally Displaced Persons(IDPs)

\begin{abstract}
"Internally displaced people are those persons or groups of persons who have been forced to flee or to leave their homes or place of habitual residence in particular as a result of or in order to avoid the effect of armed conflict, situations of generalized violence, violation of human rights or natural or man-made disasters and who have not crossed an internationally recognized state border." [2]
\end{abstract}

Another definition of IDPs has been formulated by the United Nations Commission on Human Rights in 1992. It defines internally displaced persons as "those persons who have been forced to flee their homes suddenly and unexpectedly in large numbers, as a result of armed conflict, internal strife, systematic violations of human rights or natural or man-made disasters, and who are within the territory of their own country." [3]

However, the definition put forward by Francis Deng is the most widely used definition on IDP and it has been accepted by the United Nations, the World Bank and the World Commission on Dam as their guiding principles. The definition laid down by the Guiding Principles on IDPS includes those displaced by natural and man-made disasters as IDPs and states, "Every human being shall have the right to be protected against being arbitrarily displaced [4] from his or her home or place of habitual residence." [5]

In the context of development induced displacement, it is important to note that displacement is both ,physical displacement $^{\text {ee }}$ and , livelihood displacement ${ }^{\mathrm{ee}}$. In the narrow sense displacement results in the physical displacement of people living in the reservoir or other project area. This occurs not only due to the inundation caused by reservoirs but also due to the installation of project facilities and associated infrastructure. The physical displacement is involuntary and involves coercion and force. However, the inundation of land and alteration of riverine ecosystems, whether upstream or downstream, also affects the resources available for land and riverine based productive activities. In the case of communities dependent on land and the natural resource base in India and elsewhere, this often results in the loss of access to traditional means of livelihood, including agricultural production, fishing, livestock grazing, fuel-wood gathering, collection of forest products and so on. This not only disrupts local economies, but also effectively displaces people from access to a series of natural resource and environmental inputs into their livelihoods. This form of livelihood displacement deprives people of their means of production and dislocates them from their existing sociocultural milieu [6]. In other words, a very large section of people may not be directly affected due to acquisition of land, but indirectly due to the changes in the land-use pattern, as a consequence of the project. [7]

In the context of the above, it is also important to discuss the concept of "Hydraulic Civilization "e put forward by Karl A Wittfogel in his book Oriental Despotism, where he termed those civilizations as hydraulic civilizations whose agriculture was dependent upon large-scale waterworks for irrigation and flood control. Thus, hydraulic societies are basically agrarian societies in which agriculture based hydraulic and non hydraulic constructions are managed and developed by a strong government for productive and protective purposes [8] and whenever large scale waterworks for irrigation require substantial and centralized control, government representatives monopolize political power and dominate the economy through governmental directions [9]. He coined the term to describe the social system that relied on the productivity of irrigated agriculture and its surplus production, which stimulate and sustain development, laws, public works and government control needed for central leadership and thus, led to the evolution of political and social structures that construct and manage large scale irrigation system. [10] Wittfogel has listed India among one of those ancient hydraulic civilizations like Egypt, Mesopotamia, China, Mexico and Peru. Here it is important to note that the Indian state has been seeking to control its water resources by implementing various policies and acts such National Water Policy, National Hydro Power Policy etc. and by commissioning various boards and

Volume 6 Issue 1, January 2017 


\section{International Journal of Science and Research (IJSR) \\ ISSN (Online): 2319-7064}

Index Copernicus Value (2015): 78.96 | Impact Factor (2015): 6.391

committees like the Water Board, the Inter-State Water Commission etc. India's plan to commission hydro-power projects in various parts of the country also reflects the hydraulic nature of the Indian state.

Here, it is imported to mention Vandana Shivaes critique on India's hegemonic dimension of development that development, a post-colonial project based on commercialization of resources and capital accumulation, is associated not only with the creation of profit and surplus but also with the problem of poverty and dispossession. As such, development based on exploitation and degradation of nature often results in loss of political control over naturees sustenance base and in eroding traditional land use rights of those who have been displaced and affected by development projects. [11] On the other hand, Ramachandra Guha put emphasis on Gandhian way of reshaping development projects to the local levels and gives priority to common property resources for restoration of community based environment management. Thus, the scholar tries to link the conflict over natural resources to the very process of development as development projects like dams have negative impacts on nature. As such degradation of environment directly threatens survival and livelihood options in the Indian context, whereas, environmental conflicts in the West have emerged out of threats to health and leisure options. In Western societies environmental conflicts by and large run parallel to consumer society without questioning its sociological basis, but environmental conflicts in Third World Countries like India have close connections to questions of sustenance and survival and have prompted a critique both of consumerism and of uncontrolled economic development. [12]

National policies and its shortcomings:

The Government of India has been responsible for the uprooting and displacement of some two to five crore citizens of the country since independence in the name of development planning and it has ensured the rehabilitation of only a few out of this total number. [13] The World Bank has also been pressurizing the Government of India to come up with a National Rehabilitation Policy. India has so far drafted many bills and has approved several Resettlement and Rehabilitation Policies such as the Land Acquisition Act of 1894(Amended in 1984), the National policy on Resettlement and Rehabilitation for the Project Affected Families, 2003, the National Policy for Resettlement and Rehabilitation, 2007, the Land acquisition, Rehabilitation and Resettlement Bill, 2011, Right to Fair Compensation and Transparency in Land acquisition, Rehabilitation and Resettlement Act, 2013, Right to Fair Compensation and Transparency in Land Acquisition, Rehabilitation and Resettlement (Amendment) Ordinance, 2014 and the Right to Fair Compensation and Transparency in Land acquisition, Rehabilitation and Resettlement (Amendment) Ordinance, 2015. But most of them have been found to be lacking in many ways. Therefore, the Supreme Court too held in 2000 that a rehabilitation package has to be provided before people are actually displaced and thus, the draft national policy should involve a commitment to ensure that displaced people are better off after than before displacement. Though successful rehabilitation with development is a fundamental commitment and responsibility of the state [14], yet the
Government of India has taken a firm stand that the rehabilitation would not be a prime consideration while acquiring land for, public interest ${ }^{\text {ee }}$. [15]

It is also observed that project authorities do not consider the problems of displacement and rehabilitation as important aspects of the project and concerned authorities seldom undertake detailed and systematic surveys of the population to be displaced. [16] Resistance against dam, therefore, is generally about the recognition and restoration of rights. The resistance movements against forced displacement are basically resistance to displacement, inadequate resettlement programmes and the very development rationale that displaced them and the lack of control that displaced people have over determining their livelihoods. Resistance also takes place due to exclusion from categories/labels such as ,project affected person ${ }^{\text {ee }}$ or compensation packages that would help to restore the rights and livelihoods of displaced people as the conventional compensation packages are very inadequate in capturing loss and the hidden costs of forced displacement, and intangible social and cultural issues [18].

The Plight of the IDPs of the Lower Subansiri HydroElectruc Project(LSHEP):

This paper examines the issues of land acquisition, resettlement and rehabilitation concerning the LSHEP on the basis of empirical data collected through a field survey in Gerukamukh village of Dhemaji District, Assam and Litmoi of Gensi circle, West Siang District, Arunachal Pradesh. An attempt has also been made to examine the nature of land acquisition and resettlement measures taken both in the upstream and downstream of the project and to analyze the peoples ${ }^{\text {ee }}$ perception on the project.

The survey of the Gensi village of Likabali Sub-division of West Siang District reveals that two villages of Lower Subansiri district of Arunachal Pradesh, viz; Gangi and Nsiberite, have been severely affected by the Lower Subansiri Hydro Electric project. A total of 1094 people seem to have been affected by the project. Out of 116 affected families, 77 families from both the villages have been displaced involuntarily by the hydel project and total 1225 hectors of private land have been acquired. Among these 77 project affected families, 29 lost their agricultural land, but not their homestead. As a result, the affected people moved to the Gensi village which is almost $90-95 \mathrm{~km}$ far from their villages in search of alternatives. It is important to mention that the people of these affected villages are mostly dependent on the river Subansiri and the climate of the area for agriculture either jhum cultivation or "Paani Kheti"(Deep Water Rice Cultivation) and on common property resources, especially on timber and bamboo for their livelihood.

It is worth mentioning that the people of Arunachal Pradesh were well informed about the possible acquisition of land before the installation of the projects. Regarding compensation, the respondents informed that they had been given almost $80 \%$ cash compensation for the land and that the compensation process is still going on. Construction of two resettlement camps or model villages, viz; Tarap and Nsiberite Rijo is also going on for the people of Gangi and 


\section{International Journal of Science and Research (IJSR) \\ ISSN (Online): 2319-7064}

Index Copernicus Value (2015): 78.96 | Impact Factor (2015): 6.391

Nsiberite respectively equipped with facilities like health centers, drainage system, electricity, model schools etc. Regarding employment, it is claimed by the respondents that one member from 7-8 out of 77 affected families got employment in the project based on their educational qualification whereas, the Government of Arunachal Pradesh and NHPC authorities claimed that 30/40 local youths were employed in the project through campus interview. A few are engaged in temporary jobs under contractors and as drivers. Affected families also stated that most of them have also started petty business or have opened shops either in their locality or in the project site from the cash compensation they received from the authority for the land they have lost for the project.

It has also been observed from the field survey that though the people of Arunachal Pradesh have received almost $80 \%$ of compensation and resettlement benefits from the state Government and the NHPC authorities, yet some of the affected people are not satisfied with the resettlement package and the modern facilities provided in the resettlement sites. It has been alleged by the local people that the project has disrupted their community network and their traditional way of life and as such has transformed their traditional tribal lifestyle. People who have lost only agricultural land, but not homestead land have refused to move out from their villages, viz., Gengi and Nsiberite, and it has been reported that the Village Action Committee of Gengi is trying to mobilize the people against the LSHEP due to its adverse effect on their culture and traditional way of life.

Most of the people of the Gerukamukh village of Dhemaji district of Assam are tribals, especially Mishings of Assam and Adi people from Arunachal Pradesh and the rest are tea tribes, Koch-Kalita, Ahom, Sonowal Kacharis, Koibarta, Nepali etc. Majority of them are poor marginalized farmers, carpenters and daily wage earners. The following diagrams show that majority of the respondents of the Gerukamukh village are Scheduled tribes and scheduled castes. They constitute more than $60 \%$ of the total population. Again, $42 \%$ of the respondents are engaged in agriculture and allied activities and almost $70 \%$ of those engaged in Agriculture and allied activities are STs and SCs. So it is apparent that the STs and SCs, who are dependent on agriculture for their livelihood, are the worst affected sections of the population due to the construction of the LSHEP.

It is significant to note that since no private land has been acquired so far by the NHPC for the LSHEP in Assam and, therefore, people of the village under study have not been physically displaced because of the Lower Subansiri Hydel Project but they are indirectly displaced from access to natural resources and environmental inputs for their livelihood. However, the respondents apprehended that there is possibility of direct displacement of population in the near future. The project was set up in a reserve forest area known as Subansiri Reserve Forest. Before the project was installed, the local people used to collect firewood, medicinal herbs and even used the forest land for the production of seasonal vegetables and as grazing fields. But now the NHPC authorities have declared the area as prohibited area and hence the local people are deprived of their access to the forest.

The NHPC proposed to invest $1 \%$ of the total cost of the project for development of the local people of Assam. In reality, however, the NHPC has not carried out any developmental activities for the local people except construction of the road and the reconstruction of a bridge on the Chaoldhuwa River. It may be noted that the river Chaoldhuwa is a tributary of Subansiri and the bridge over the river had collapsed due to the sudden release of water from the Ranganadi Hydel Project in 2005 and it had led to artificial flood in the downstream of the project.

Another important finding of the survey is the allegation of the Adi people that approximately 570 hectors of their ancestral land have been acquired for the project and that they are not compensated yet for the acquisition and have not been provided any developmental benefits, either from the project authorities or from the Assam Government. The Adi people consider themselves as the worst sufferers of the project because they gain support neither from the Arunachal Government nor from the Assam Government. It is important to note that these Adi people are not original residents of the Gerukamukh village. It has been reported by the local people that they are originally from Arunachal Pradesh who have come to the village after the commencement of the project.

Regarding resettlement and rehabilitation, the respondents informed that only a few local youth have managed to get contractual jobs and some of them work as daily wage earners. It is important to mention here that there is no official record on the employment of these contractual jobholders as they work only under contractors. Therefore they are protesting against the NHPC authorities and a case has been filed against it in Lakhimpur district court.

\section{Movement against big dam in Assam:}

Certain core issues raised by the protesting organizations like the People's movement for Subansiri Valley, the Krishak Mukti Sangram Samiti (KMSS), All Assam Students ${ }^{\text {ee }}$ Union (AASU), and the Takam Mishing Parim Kebang (TMPK) etc. have been identified in connection with land acquisition, resettlement and rehabilitation of the Displaced and Project Affected Persons of the LSHEP to examine the nature of the anti-dam movement. Here it is important to note that LSHEP has led to internal displacement both in Assam and Arunachal Pradesh. But the People of Arunachal Pradesh have been compensated for it and as such, people are not protesting against the project in an organized manner although the Village Action Committee of Gengi village tried to mobilize the villagers against the project. Thus, it is apparent that the protesting organizations are based mostly in Assam.

Regarding political affiliation of the major protesting organizations, the KMSS has formed its own political party named Gana Mukti Sangram in July, 2015. It has also been seeking to forge solidarity with national civil society movements like Narmada Bachao Andolan and movement led by Anna Hazare. Another protesting organization, the 


\section{International Journal of Science and Research (IJSR) \\ ISSN (Online): 2319-7064}

Index Copernicus Value (2015): 78.96 | Impact Factor (2015): 6.391

TMPK backs a political party viz. Gana Shakti Party which tries to represent the interest of the Mishing community as a whole. [17]

The central issues concerning the LSHEP are the safety and security of the dam, suitability of the present location of the dam, internal displacement and other downstream impacts. A large number of organizations started agitation against the construction of the LSHEP after the Expert Group made its Report public, causing road blockades, obstructing transportation of construction materials and equipments to the project site. The AASU, KMSS, AJYCP, TMPK and other organizations resorted to agitations like dharna, sit-instrike, demonstration, road blockades etc. throughout Assam.

Here, it is important to note that the people of Assam have been protesting against the LSHEP since 2001 under the banner of the above mentioned organizations and pressurizing the union Government, State Government as well as the NHPC authorities to halt the construction work until cumulative downstream impact assessment study becomes mandatory. As such, these organizations are protesting against the construction of mega dams not only to mitigate the adverse impacts of mega dams but also to place the right of the displaced and affected people in the overall developmental agenda. Thus, the main concern of the protesting organizations is that the people of the downstream or the DPs and PAPs are sacrificing their lives and livelihood in the name of national development though Assam will get only $25 \mathrm{mw}$ of free power from 168 mega dams with the installed capacity of $70,000 \mathrm{MW}$ of power.

The study shows that the LSHEP is facing resistance from local citizens and other civil society organizations in Assam on the issue of internal displacement of people and on the faulty clearances to the project without comprehensive downstream impact study. Moreover, as the project is situated in an area vulnerable to flood, landslide and earthquake, it has created a psychological trauma among the downstream dwellers about the possible collapse of the dam due to natural calamities. Again, the building of dams in China and its plan to divert the river Brahmaputra questions the feasibility of the dam itself.

The study also revealed that both private and public land has been acquired in the upstream of the project but in the downstream only CPRs have been acquired for the project. Since no private land has been acquired so far for the LSHEP in Assam, people of the village under study have not been displaced directly by the project, but they are indirectly displaced by the project as it was set up in a forest area. Before the installation of the project, people used the forest area for the production of seasonal vegetables and as grazing field. It is important to note that the local people of both downstream and upstream are unfamiliar with modern health care facilities and they use medicinal herbs that were available in the forest area for treatment. Thus, the acquisition of CPRs not only deprived them from their means of sustenance but also affected their traditional practices.

The Adi people of Arunachal Pradesh who have been forced to move to Assam claimed that they have lost approximately
570 hectares of their ancestral land for the project. Though the DPs and PAPs of the upstream have been compensated and rehabilitated by the Arunachal Government, these Adi people have not got any benefit from the project because they have not been provided any compensation either by the Union Government or by the state governments of Assam and Arunachal Pradesh. It is important to note that though the Arunachal Pradesh Government and NHPC authorities made provisions for the rehabilitation of the DPs and PAPs of the LSHEP in Arunachal Pradesh itself, the Adi people had moved to Assam on their own and resided in the forest area. These Adi people used to move from place to place in search of livelihood alternatives as reported by the village headman of the Adi village, Durpai Dasi Gaon. This may be the reason why the Adi people have not got any benefit from the Governments of Assam and Arunachal Pradesh.

It is also observed from the field survey that only two organizations viz., TMPK and AASU are active in the project area. It is alleged by the local people that KMSS and other protesting organizations staged protests mostly in Lakhimpur, Dhemaji, Tezpur and Guwahati and other district head quarters but they have never protested at the project site yet. The people of Arunachal Pradesh are also critical about the role of the protesting organizations in Assam as none of these organizations have visited the affected villages of Arunachal Pradesh and they have not tried to focus on the problems faced by the displaced and project affected people of Arunachal Pradesh. The affected people also alleged that the protesting organizations in Assam are protesting only to fulfill their vested interests. They also claimed that the proposed hydro-electric projects have only benefited the Union and state Government of Arunachal Pradesh but undermines the life and security of the people living in the Subansiri valley. Here, it is also important to mention the allegation of the Indian intelligence that the leadership of the KMSS and the TMPK have some Marxist-Leninist leanings and orientations and as such have mobilized opinion against big dams which is an important component of anti-state movements in India.

However, it is evident from the study that the issues raised by the protesting organizations are very crucial to the problem of internal displacement. Though no physical displacement has taken place in Assam so far, yet these organizations are trying to build their support base on the basis of the perceived psychological threat regarding the collapse of the dam due to natural calamities like earthquake. These organizations are also successful in focusing the issue of livelihood displacement due to the construction of the dam and its adverse effect on the people, environment and riverine ecology. These organizations are also very critical about the safety and security of the dam as it is situated in an area vulnerable to earthquake, flood and landslide and the seismic design parameter of the dam is not adequate to prevent earthquake of 8.5 magnitudes. These organizations are also not satisfied with the geological structure of the project. One of the main allegations of these organizations is that the project does not meet the environmental safety parameters as the project has been given environmental clearance without conducting cumulative impact assessment study. Moreover, the project does not have provision for flood moderation. 


\section{International Journal of Science and Research (IJSR) \\ ISSN (Online): 2319-7064}

Index Copernicus Value (2015): 78.96 | Impact Factor (2015): 6.391

It is important to note that all the protesting organizations are based in Assam. They are raising issues mainly regarding the safety and technical viability of the dam. While they have blocked the transportation of construction materials and equipment to the project site, they have refrained from visiting the project area. On the other hand, significant displacement has taken place in the upstream of the project. However, it is observed that at present no such protest movement is going on in Arunachal Pradesh against the LSHEP. Here, it may be noted that the people of Arunachal Pradesh too protested against the project at the initial stage under the leadership of T. Dasi, the President of the then Village Action Committee. During an interview with the Research Scholar, Mr Dasi alleged that he was arbitrarily removed by the Arunachal Government from his position in presumably to suppress the movement.

It is important to note in this context that protesting organizations like KMSS are keeping a distance from the project site, thereby alienating themselves from the affected people. There is, thus, a gap between the huge mobilizing potential around a big dam like LSHEP and the failure to utilize this potential for organizing a genuine mass movement against LSHEP. In/other words, although the protesting organizations have raised certain pertinent issues relating to the LSHEP, they have failed to convert the resistance against this dam into a popular movement.

The distrust of the project affected people came to the fore when it was pointed out by some respondents that the protesting organizations had stalled the transportation of construction materials for some time and thereafter, they allowed the same, presumably due to some understanding with the NHPC. This clearly reveals that the organizations have not been able to earn the confidence of the local people in the project site as such.

Another significant issue that emerges out of the politics of LSHEP is that the protesting organizations are seeking to mobilize public support on the ground that Assam will not get an equal share of free power vis-à-vis Arunachal Pradesh after the completion of the project. This shows that the issue of power sharing is an integral aspect of politics of big dams which are located in more than one state.

It may also be noted that the response of the Union and the state governments to the issues raised by the protesting organizations had been confined mainly to the constitution of committees. However, it appears that none of these committees are multi-disciplinary. Most of the members of these committees are only technical experts. But the people are demanding a multi-disciplinary committee so that the study covers every aspect of the problem of affected peopleeconomic, political, social, psychological, cultural or environmental, in order to make the study a comprehensive and systematic one. The protesting organizations are also opposing the state government's decision to appoint technical experts from Switzerland to examine the technical aspect of the project. Instead these organizations are demanding a multi-disciplinary body, comprised of experts who have knowledge of the indigenous culture, tradition, and environment, to study the cumulative impact of all the 168 proposed mega dams to be built in Arunachal Pradesh.

\section{Conclusion}

From the above discussion it is clear that the LSHEP has led to displacement of people living both upstream and downstream of the project. Some are directly displaced by the project whereas others are being alienated from their means of livelihood. Majority of the tribal people residing in the vicinity of the project site are either dependant on agriculture and allied activities or on CPRs for centuries, but the LSHEP has altered their traditional way of living by introducing modern facilities which are unfamiliar to their culture and tradition. Loss of traditional means of livelihood and community networks and the fear of possible collapse of the dam due to natural calamities have undermined their cultural rights as well as their right to life.

\section{References}

[1] Erin D Mooney, "Towards a Protection Regime for Internally Displaced Persons" in Edward Newman and Joone Van Selm (eds), Refugees and Forced Displacement: International Security, Human Vulnerability and the State, United Nations University Press, New York, 2003, pp.159-161. Also see, S.Dutta, "Internally Displaced People In Arunachal Pradesh" in C. Joshua Thomas (ed) Dimensions of Displaced People in North East India, Regency Publication, New Delhi, 2002. p.202.

[2] W.C. Robinson, Risks and Rights :The Causes, Consequences and Challenges of Development Induced Displacement, The Brookiing Institutiion, Washington DC,2003, p.7.

[3] Commission on Human Rights, Analytical Report of the Secretary General on Internally Displaced Persons, E/CN.4/1992/23, United Nations, 1992.

[4] Displacement in cases of large-scale development projects which are not justified by compelling and overriding public interests.

[5] Article 6(2c), International Guiding Principles on Internally Displaced Persons cited in W.C. Robinson, opcit, p7.

[6] Dams and Development: The Report of the World Commission on Dams, Earthscan Publications Limited, London. November, 2000, pp.103,104.

[7] Enakshi Ganguly Thukral (ed), Big Dams, Displaced People: Rivers of Sorrow Rivers of Change, Sage Publication, New Delhi, 2002.p14.

[8] Karl A Wittfogel, Oriental Despotism: A Comparative Study of Total Power, Yale University Press, New Haven, 1957.

[9] KarlAWittfogel,"TheHydraulic Hypothesis", http://www.riseofthewest.net/thinkers/wittfogel105.htm accessed on $8 / 26 / 2014$.

[10] Richard E. Howitt, "Is Californiaes Future Hydraulically Sustainable?", California Agriculture, Vol.54, No.2, 2000,p.10.

[11] Vandana Shiva, Staying Alive: Women, Ecology and Development, Zed Books, London, 1988, pp. 1-13. 


\section{International Journal of Science and Research (IJSR) \\ ISSN (Online): 2319-7064}

Index Copernicus Value (2015): 78.96 | Impact Factor (2015): 6.391

[12] Madhav Gadgil and Ramachandra Guha, "Ecological Conflicts and Environmental Movements in India", in Peter Utting (ed), Revisiting Sustainable Development, United Nations Research Institute for Social Development, Geneva, 1994, pp.205-232.

[13] Jai Sen, "National Rehabilitation Policy: A Critique", Economic and Political Weekly. Vol.30, No.5, Feb 4, 1995, p.241.

[14] Walter Fernandes, "Displacment and Rehabilitation" Economic and Political Weekly, Vol.30, No.39, September 30, 1995, p.2460.

[15] Mahendra P Lama, "Internal Displacement in India: Causes, Protection and Dilemmas." in Forced Migration Review, August 2000 as cited in W.C. Robinson, Risks and Rights :The Causes, Consequences and Challenges of Development Induced Displacement, The Brookiing Institutiion, Washington DC,2003 p.25.

[16]Enakshi Ganguli Thukral (ed),op.cit, p.2.

[17]Loc.cit.

[18] Manoranjan Pegu, "Student Organizations, TMPK and Politics", Voice of the Oppressed, August 5, 2011. 